daily and nighttime DBP variability and improves daily profiles of SBP and DBP.

\title{
References:
}

1. Petrie J. R., Guzik T. J., Touyz R. M. Diabetes, hypertension, and cardiovascular disease: clinical insights and vascular mechanisms. Can J Cardiol. 2018. Vol. 34 (5). P. 575-584.

2. Pavlou D. I., Paschou S. A., Anagnostis P. [et al.] Hypertension in patients with type 2 diabetes mellitus: targets and management. Maturitas. 2018. Vol. 112. P. 71-77.

3. Kario K., Ferdinand K. C., O'Keefe J. H. Control of 24-hour blood pressure with SGLT2 inhibitors to prevent cardiovascular disease. Prog Cardiovasc Dis. 2020. Vol. 63 (3). P. 249-262.

4. Berra C., Manfrini R., Regazzoli D. [et al.] Blood pressure control in type 2 diabetes mellitus with arterial hypertension. The important ancillary role of SGLT2-inhibitors and GLP1-receptor agonists. Pharmacol Res. 2020. 160: 105052.

5. Rajzer M., Kawecka-Jaszcz K., Wojciechowska W. Antihypertensive treatment for patients with hypertension and diabetes type II-current clinical research. Przegl Lek. 2003.Vol. 60 (2). P. 111-115.

DOI https://doi.org/10.30525/978-9934-588-81-5-1.2

\section{КЛІНІЧНИЙ ВИПАДОК СИНДРОМУ ЖИРОВОЇ ЕМБОЛІЇ}

\author{
Афанасюк O. I. \\ кандидат медичних наук, доцент, \\ дочент кафедри внутрішньої медицини № 3
}

Вінницький національний медичний університет імені М. I. Пирогова

\section{Шмалій В. І.}

кандидат медичних наук, доцент, дочент кафедри внутрішньої медицини № 3

Вінницький національний медичний університет імені М. І. Пирогова

Яковець О. О.

лікар-терапевт вищої категорії

Комунальне некомериійне підприємство «Вінницька иентральна районна клінічна лікарня» Вінницької районної ради м. Вінниця, Україна

Жирова емболія (ЖЕ) - це множинна оклюзія судин краплинами жиру, які найчастіше попадають в кров'яне русло при переломах тру- 
бчастих кісток. Термін запропонований Ценкером, який знайшов краплини жиру в капілярах легень у пацієнтів, які померли після значної травми скелетних кісток $[1$, с. 48$]$. ЖЕ виникає у $60-90 \%$ випадків травм. Якщо виникають виражені клінічні симптоми, тоді більш коректно вживати термін «синдром жирової емболії» (СЖЕ), який виникає лише у 5-10 \% пацієнтів, в яких була діагностована політравма скелетних кісток. Летальність від СЖЕ складає 1-15\%. Однак серед причин розвитку ЖЕ слід віднести кардіогенний та анафілактичний шоки, панкреатит, вдалу реанімацію після раптової зупинки серця. У більшості випадків клінічна картина ЖЕ малоспецифічна і маскується під різні захворювання, такі як пневмонія, респіраторний дистрессиндром, ТЕЛА та інші [1, с. 48]. Клінічна картина ЖЕ має характерні чотири симптомокомплекси: 3 боку центральної нервової системи (ЦНС), що проявляється порушенням психіки, свідомості різного ступеня аж до коми, можливі менінгіальні ознаки, судоми, парези та паралічі. Другий симптомокомплекс включає зміни з боку дихальної та серцевої систем - виникає гостра дихальна недостатність по типу респіраторного дистрес-синдрому, що характеризується больовим синдромом за грудиною, задишкою, патологічним диханням аж до зупинки, можливий кашель 3 мокротою, виражене зниження сатурації кисню, ознаками гострої серцевої недостатності по типу набряку легень. Крім того, виникає стійка невмотивована тахікардія, яка може розцінюватись, як рання ознака розвитку синдрому ЖЕ. Третій симптомокомплекс характеризує зміни шкіри внаслідок капіляропатії, яка виникає під дією вільних жирних кислот і проявляється петехіальними висипами на щкірі голови, в тому числі слизових оболонках (порожнини рота, кон'юнктиві) та верхнього плечового поясу. Четвертий симптомокомплекс характеризується постійною фебрильною лихоманкою, яка не піддається лікуванню звичайними антипіретичними препаратами, так як виникає внаслідок порушення роботи центру терморегуляції в головному мозку під дією вільних жирних кислот [1, с. 49]. Актуальним питанням залишається діагностика СЖЕ, особливо у пацієнтів 3 коморбідними станами, незважаючи на тривале вивчення цієї проблеми, та має високі показники летальних наслідків [2, с. 41].

У хірургічне відділення комунального некомерційного підприємства «Вінницька центральна районна лікарня» Вінницької районної ради в січні 2020 року госпіталізували пацієнтку 72-х років із діагнозом Закритий гвинтоподібний підвертлюговий перелом правої стегнової кістки зі зміщенням. Зі слів пацієнтки за два дні до госпіталізації в побуті вона впала з висоти власного тіла. При первинному огляді патологічних змін з боку дихальної, серцево-судинної систем хвора не мала. Відмічалась ясна свідомість. Під час передопераційного консультування терапевтом 
відмічався синусовий ритм. Проведений доплер судин нижніх кінцівок, результати якого свідчили про відсутність ознак флеботромбозу, тромбофлебіту, вени спадались при компресії датчиком. На ЕхоКС відмічалась гіпертрофія лівого шлуночка, відсутність розширення порожнин і збережена фракція викиду (55\%). Іншої супутньої патології пацієнтка не вказувала. Хворій було проведено оперативне втручання: закрита репозиція, фіксація перелому стержнем PFNa. На наступну добу після операції черговий лікар реанімаційного відділення, куди була переведена пацієнтка після операції, відмітив деяку загальмованість, за шкалою ком Глазго 13-14 балів. Відмічались скарги на загальну слабкість, незначний біль у ділянці післяопераційної рани. За дві години з'явилися дискомфорт у грудній клітині, задишка. Відмічалось деяке зниження артеріального тиску до 100/60 мм рт. ст. (при госпіталізації 120/70 мм рт. ст.) та підвищення частоти серцевих скорочень до 110 уд/хв. Стан був розцінений як гострий коронарний синдром. Призначено обстеження на тропоніни, D-димер, повторна електрокардіограма, консультація терапевта, невролога. Тропоніни, зміни на електрокардіограмі не мали переконливих специфічних ознак гострого коронарного синдрому, D-димер відповідав віковим референтним значенням. Невролог не відмітив вогнищевої симптоматики. На другу добу після оперативного втручання відмічалось більш виражене погіршення свідомості (за шкалою ком Глазго 9-10 балів - сопор) та поява лівобічного геміпарезу. В зв'язку з прогресуючим погіршенням стану свідомості та рухової активності виконана спіральна комп'ютерна томографія (СКТ), Були виявлені зміни: гостре порушення мозкового кровообігу за ішемічним типом правої потиличної частки. Також наростали ознаки гострої лівошлуночкової недостатності: посилилась задишка, знизилась сатурація кисню до 89\%, при аускультації легень відмічались вологі дрібноміхурцеві хрипи в нижніх відділах легень. Призначена діуретична терапія не давала очікуваного ефекту. На третю добу після оперативного втручання підвищилась температура тіла до $38^{\circ} \mathrm{C}$. Виявлені зміни були розцінені, як прояв нижньодольової двобічної пневмонії, підтвердженої рентгенологічно вогнищевими змінами. Призначена двокомпонентна антибактеріальна терапія згідно діючої настанови $з$ лікування пневмонії, антипіретики. Стан хворої залишався стабільно важким. До кінця третьої доби після операції на шкірі грудної клітки, обличчя, передпліч та стегон з'явилась петехіальна висипка. Була повторно виконана коагулограма i визначення тромбоцитів. Відмічались нормальні показники коагулограми, збільшення фібриногену до 6 г/л та зниження тромбоцитів до $100 * 10^{9}$ /л. В загальному аналізі крові з'явилась легка анемія (гемоглобін 104 г/л), лейкоцитоз (13,8*109/л), підвищилась швидкість осідання еритроцитів (ШОЕ) до 40 мм/год. Виникла підозра син- 
дрому жирової емболії. Стан хворої був оцінений за балами субклінічної форми ЖЕ за О.Ю. Пащуком. Так, наявність тахікардії більше 90 уд/хв - 20 балів, гіпертермія понад $38^{\circ} \mathrm{C}-10$ балів, зміна свідомості - 20 балів, гіпокоагуляція - 5 балів, підвищення ШОЕ - 1 бал. Сума балів була 56 балів, що вказувало на маніфестну клінічну форму ЖЕ [1, с. 49]. Додатково до антибактеріальної терапії призначено специфічне лікування ЖЕ: ліпостабіл 30 мл тричи на добу, ессенціале 5 мл на аутокрові двічи на добу, клексан 0,4 підшкірно 1 раз на добу. Також проводилась профілактика гіповолемії. Стан хворої стабілізувався. Хвора була виписана із стаціонару із залишковими ознаками після гострого порушення мозкового кровообігу.

Отже, діагностика жирової емболії значно утруднена, адже клінічна картина та результати лабораторно-нструментальних методів дослідження подібні до інших захворювань. Так, у даної пацієнтки проводилась диференційна діагностика жирової емболії із гострим коронарним синдромом, гострим порушенням мозкового кровообігу, гострою лівошлуночковою недостатністю та пневмонією. Вирішальним у постановці діагнозу було виявлення петехіального висипу, який зустрічається лише у половини хворих. Крім того, клінічна картина мала характерні симптомокомплекси і відповідала маніфестній формі за бальною оцінкою. Вчасна діагностика синдрому жирової емболії сприяла призначенню адекватного і своєчасного лікування.

1. Мирджалилов Ф.Х., Хакимов Р.Н., Каримов Б.Р., Исмаилов А.Дж. Синдром жировой эмболии: этиология, патогенез, диагностика и лечение. Вестник экстренной медищины. 2018. Том 11. № 1. С. 48-52.

2. Дужий І. Д., Яковенчук Н. М., Ель-Асталь Раєд Зіяд, Харченко С. В. Жирова емболія у травматології. Kharkiv surgical school . 2011. № 4(49). C. 41-45. 